\title{
In focus in Vienna: the cell nucleus
}

\author{
Klara Weipoltshammer $^{1} \cdot$ Christian Schöfer $^{1}$
}

Accepted: 2 February 2016 / Published online: 18 February 2016

(C) Springer-Verlag Berlin Heidelberg 2016

Focus of this Special Issue of Histochemistry and Cell Biology is nuclear structure and function, which was the topic of last year's Wilhelm Bernhard Workshop in Vienna, Schloss Wilhelminenberg. The 24th Wilhelm Bernhard Workshop on the cell nucleus hosted the 57th Symposium of the Society for Histochemistry, thus bringing together experts on the cell nucleus with scientists exploring cellular processes by means of diverse in situ techniques and highend microscopic approaches. The local organizers of this joint meeting were Christian Schöfer and Klara Weipoltshammer of the Center of Anatomy and Cell Biology, Medical University of Vienna, Austria.

Chromatin is a prominent nuclear organizer. After decades of eminent contributions to the understanding of chromatin arrangement, Marion and Thomas Cremer (Ludwig Maximilians University, Martinsried, Germany) jointly held the prestigious Wilhelm Bernhard Lecture 2015 focusing on a "Dynamic nuclear landscape based on co-aligned active and inactive nuclear compartments." Tom Misteli (NIH, Bethesda, USA), the Wilhelm Bernhard medalist of 2013, who could not attend the previous WBW meeting in Debrezen, Hungary, presented an overview on "Nuclear architecture and disease." An important aspect in diseases, in particular in malignancy, is altered nuclear gene positioning which is the topic of the paper by Meaburn et al. (2016) "A study on gene repositioning in breast

Christian Schöfer

christian.schoefer@meduniwien.ac.at

Klara Weipoltshammer

klara.weipoltshammer@meduniwien.ac.at

1 Department for Cell and Developmental Biology, Center for Anatomy and Cell Biology, Medical University of Vienna, 1090 Vienna, Austria and prostate cancer" included in this issue. Evi Soutoglou (Illkirch, France) received the Wilhelm Bernhard Young Investigator's award and presented her work on spatial organization of DNA repair within the nucleus.

In the session of the Society for Histochemistry, Wendy Bickmore (MRC Human Genetics Unit, University of Edinburgh, UK) presented her work entitled "Transcription, chromatin structure and nuclear organization: cause and consequence" as Robert Feulgen Lecture 2015. A particular important nuclear domain involved in chromatin organization represents the nuclear periphery and the implications for genome functions is topic of a review (Lemaitre and Bickmore 2015).

Hiroshi Kimura (Tokyo Institute of Technology, Yokohama, Japan) was awarded the Robert Feulgen Prize 2015 of the Society for Histochemistry and presented his results on in vivo detection of epigenetic modifications of endogenous proteins (Kimura et al. 2015).

The journal of the Society for Histochemistry, Histochemistry and Cell Biology, sponsored an honorary lecture, which was held by Markus Sauer (University of Würzburg, Germany), entitled " $d$ STORM coming of age: from concepts to biological impact." In consequence, particular focus has been laid on the avoidance of artifacts introduced by single-molecule localization microscopy (Burgert et al. 2015).

Several of the different aspects of nuclear structure and function that were discussed at the joint meeting are represented by reviews or original articles in this special issue. In the review "Morphology of nuclear transcription," transcription by RNA polymerases I and II is compared with respect to structural and dynamic aspects of their nuclear arrangements (Weipoltshammer and Schöfer 2016). The article "Nucleolar DNA: the host and the guests" reviews our current understanding of structure and function of 
this characteristic nuclear compartment (Smirnov et al. 2016). Structural determinants are of crucial importance for nuclear organization. Current knowledge on nuclear actin is reviewed in "Actin, actin-binding proteins, and actin-related proteins in the nucleus" (Kristó et al. 2016), whereas Harata and coworkers present data on the interaction of nuclear F-actin and $\beta$-catenin (Yamazaki et al. 2016). Aspects of the growth of another structural entity, the nuclear lamina, were presented by Zhironkina et al. (2016). The involvement of nuclear lamina components in the premature aging disease progeria is reviewed in Vidak and Foisner (2016).

An extensive field covered was epigenetic mechanisms and factors in developing and adult organisms. This issue contains a study on HP1 $\beta$, H3K9me1/me 2 and H3K9me3 in mouse embryonic brain (Bartova et al. 2016) and on the enhancer element of the Danio rerio minor globin gene locus (Nefedochkina et al. 2016).

During the last years, a tremendous gain of knowledge linking aberrant nuclear processes to diverse pathologies could be observed. One example is the pathologies of the nuclear lamina (see above). Further pathology aspects discussed at the meeting were DNA damage-induced consequences for nuclear functions underlying aberrant differentiation of cells such as altered DNA damage response and generation of aneuploidy (Gerashchenko et al. 2016; Bou Saada et al. 2016).

Last but not least, the combined Wilhelm Bernhard and Society for Histochemistry meeting 2015 presented a platform for the discussion of new high-end techniques such as those to detect nuclear lipids (Kalasova et al. 2016).

\section{References}

Bartova E, Večeřa J, Krejči J, Legartova S, Pachernik J, Kozubek $S$ (2016) The level and distribution pattern of HP1 $\beta$ in the embryonic brain correspond to those of $\mathrm{H} 3 \mathrm{~K} 9 \mathrm{me} 1 / \mathrm{me} 2$ but not of H3K9me3. Histochem Cell Biol. doi:10.1007/ s00418-015-1402-7

Bou Saada Y, Dib C, Dmitriev P, Hamade A, Carnac G, Laoudj-Chenivesse D, Lipinski M, Vassetzky YS (2016)
Facioscapulohumeral dystrophy myoblasts efficiently repair moderate levels of oxidative DNA damage. Histochem Cell Biol 145. doi:10.1007/s00418-016-1410-2

Burgert A, Letschert S, Doose S, Sauer M (2015) Artifacts in single-molecule localization microscopy. Histochem Cell Biol 144:123-131. doi:10.1007/s00418-015-1340-4

Gerashchenko BI, Salmina K, Eglitis J, Huna A, Grjunberga V, Erenpreisa J (2016) Disentangling the aneuploidy and senescence paradoxes: a study of triploid breast cancers non-responsive to neoadjuvant therapy. Histochem Cell Biol 145. doi:10.1007/ s00418-016-1415-x

Kalasova I, Fáberová V, Kalendová A, Yildirim S, Uličná L, Venit T, Hozák P (2016) Tools for visualization of phosphoinositides in the cell nucleus. Histochem Cell Biol 145. doi:10.1007/ s00418-016-1409-8

Kimura H, Hayashi-Takanaka Y, Stasevich TJ, Sato Y (2015) Visualizing posttranslational and epigenetic modifications of endogenous proteins in vivo. Histochem Cell Biol 144:101-109. doi:10.1007/ s00418-015-1344-0

Kristó I, Bajusz I, Bajusz C, Borkúti P, Vilmos P (2016) Actin, actinbinding proteins, and actin-related proteins in the nucleus. Histochem Cell Biol 145. doi:10.1007/s00418-015-1400-9

Lemaître C, Bickmore WA (2015) Chromatin at the nuclear periphery and the regulation of genome functions. Histochem Cell Biol 144:111-122. doi:10.1007/s00418-015-1346-y

Meaburn KJ, Agunloyea O, Devinea M, Leshnera M, Roloffa GW, Trueb LD, Misteli T (2016) Tissue-of-origin specific gene repositioning in breast and prostate cancer. Histochem Cell Biol. doi:10.1007/s00418-015-1401-8

Nefedochkina AV, Petrova NV, Ioudinkova ES, Kovina AP, Iarovaia OV, Razin SV (2016) Characterization of the enhancer element of the Danio rerio minor globin gene locus. Histochem Cell Biol 145. doi:10.1007/s00418-016-1413-z

Smirnov E, Cmarko D, Mazel T, Hornaček M, Raška I (2016) Nucleolar DNA: the host and the guests. Histochem Cell Biol 145. doi:10.1007/s00418-016-1407-x

Vidak S, Foisner R (2016) Molecular insights into the premature aging disease progeria. Histochem Cell Biol 145. doi:10.1007/ s00418-016-1411-1

Weipoltshammer K, Schöfer C (2016) Morphology of nuclear transcription. Histochem Cell Biol 145. doi:10.1007/ s00418-016-1412-0

Yamazaki S, Yamamoto K, de Lanerolle P, Harata M (2016) Nuclear F-actin enhances the transcriptional activity of $\beta$-catenin by increasing its nuclear localization and binding to chromatin. Histochem Cell Biol 145. doi:10.1007/s00418-016-1416-9

Zhironkina OA, Kurchashova SY, Pozharskaia VA, Cherepanynets VD, Strelkova OS, Hozak P, Kireev II (2016) Mechanisms of nuclear lamina growth in interphase. Histochem Cell Biol 145. doi:10.1007/s00418-016-1419-6 